\title{
Analisis Tokoh (Najwa Shihab) Berdasarkan Teori Komunikasi Antarpribadi
}

\section{Personage Analysis (Najwa Shihab) Based on Interpersonal Communication Theory}

\author{
Syaira Arlizar Ritonga* \\ Magister Ilmu Komunikasi, Universitas Sumatera Utara, Indonesia \\ *Corresponding author: E-mail: syairaarlizar25@gmail.com
}

\begin{abstract}
Abstrak
Najwa Shihab adalah seorang news anchor dan pembawa acara di stasiun televisi Metro TV. Adapun beberapa acara yang pernah dibawakannya di stasiun televisi Metro TV yaitu program berita prime time Metro Hari Ini, Suara Anda, serta program talkshow Today's Dialogue dan Mata Najwa. Sebagai seorang presenter talkshow profesional, Najwa Shihab melakukan komunikasi antarpribadi yang baik kepada semua narasumbernya. Hal inilah yang dilakukan Najwa untuk membuat para narasumbernya merasa nyaman dan tidak merasa terintimidasi dengan pertanyaan-pertanyaan yang diberikan oleh Najwa sehingga komunikasi di antara mereka dapat terjalin dengan baik dan lancar. Najwa Shihab memiliki kompetensi komunikasi yang sangat baik ketika melakukan praktik komunikasi antarpribadi. Cara Najwa menghidupkan suasana ketika di atas panggung membawakan program acara "Mata Najwa" sangat baik. Mulai dari cara ia mendengarkan orang lain, memberikan respon terhadap pernyataan yang diberikan narasumbernya, serta proses tatap muka yang intens namun tidak memberikan kesan intimidasi, mampu diorganisirnya dengan cara yang bijak sehingga tidak menimbulkan misunderstanding di antara kedua belah pihak.
\end{abstract}

Kata Kunci: Komunikasi Antarpribadi, Mata Najwa, Najwa Shihab

\begin{abstract}
Najwa Shihab is a news anchor and host on Metro TV. Some of program that she has ever brought on Metro TV station is prime time news program Metro Today, Your Voice, talk show program Today's Dialogue and Mata Najwa. As a professional talkshow presenter, Najwa Shihab engages in good interpersonal communication to all her interviewees. This is what Najwa does to make the interviewees feel comfortable and not feel intimidated by the questions that given by Najwa so that communication between them can be well established and smooth. Najwa Shihab has excellent communication competence when conducting interpersonal communication practices. How Najwa turn on the atmosphere when on stage bring the program "Mata Najwa" very well. Starting from the way she listens to others, responds to the statements given by her interviewees, as well as the intense face-to-face process that does not give the impression of intimidation, can be organized in a wise manner so as not to cause misunderstanding between the both sides.
\end{abstract}

Keywords: Interpersonal Communication, Mata Najwa, Najwa Shihab

How to Cite: Ritonga, S.A., (2017), Analisis Tokoh (Najwa Shihab) Berdasarkan Teori Komunikasi Antarpribadi, SIMBOLIKA, 3 (2): 71-77. 


\section{PENDAHULUAN}

Najwa Shihab adalah seorang news anchor dan pembawa acara di stasiun televisi Metro TV. Beliau lahir di Makassar pada tanggal 16 September 1977. Adapun beberapa acara yang pernah dibawakannya di stasiun televisi Metro TV yaitu program berita prime time Metro Hari Ini, Suara Anda, serta program talkshow Today's Dialogue dan Mata Najwa.

Najwa merupakan alumni Fakultas Hukum Universitas Indonesia (UI) pada tahun 2000. Awal karirnya bermula pada saat beliau mengikuti program magang di stasiun televisi RCTI sebagai seorang jurnalis. Namun, pada akhirnya ia memilih untuk bergabung di Metro TV karena menurutnya stasiun TV tersebut dinilai lebih menjawab minat besarnya terhadap jurnalistik. Dari situlah Nana, begitu sapaan akrabnya, sudah mulai mencintai dunia jurnalistik. Ia sering ditawari untuk mengisi acara-acara talkshow di televisi sebagai pemandu acara.

Tahun 2006, Najwa Shihab dipilih menjadi Jurnalis Terbaik Metro TV dan masuk dalam nominasi Pembaca Berita Terbaik Panasonic Awards. Pada tahun yang sama bersama sejumlah wartawan dari berbagai Negara, ia terpilih menjadi peserta Senior Journalist Seminar yang berlangsung di sejumlah kota di Amerika Serikat dan juga menjadi pembicara pada Konvensi Asian American Journalist Association.

Tahun 2007 pernyataan terhadap profesionalisme Najwa Shihab bukan hanya datang dari dalam negeri, namun juga dari luar negeri. Terbukti Nana masuk ke dalam nominasi ( 5 besar) arena yang lebih bergengsi di tingkat Asia yakni Asian Television Awards untuk kategori Best Current Affairs / Talkshow Presenter. Pemilihan pemenang dalam ajang bergengsi ini dilakukan oleh panel juri yang beranggotakan TV broadcaster senior dari beragam Negara di Asia.

Beberapa kali Najwa juga masuk dalam nominasi Panasonic Awards (yang pada tahun
2010 berubah menjadi Panasonic Gobel Awards) sebagai kategori Presenter Talkshow Berita dan Informasi Terfavorit. Nana terpilih sebagai nominasi mulai dari tahun 2006 2015. Namun di tahun-tahun awal, Nana belum berhasil memenangkan kategori tersebut. Dan pada akhirnya di tahun 2015, Nana berhasil membawa pulang piala dari ajang bergengsi di Indonesia itu sebagai Presenter Talkshow Berita dan Informasi Terfavorit lewat program talkshow berita yang dibawakannya yaitu "Mata Najwa".

Sebagai seorang presenter talkshow profesional dalam program talkshow berita "Mata Najwa" yang tayang di stasiun televisi Metro TV, Najwa Shihab pastilah melakukan komunikasi antarpribadi yang baik kepada semua narasumbernya. Sudah banyak narasumber yang berhasil diwawancarai oleh Najwa Shihab. Mulai dari tokoh di kalangan politik, artis, maupun orang yang berpengaruh di Indonesia.

Komunikasi antarpribadi merupakan proses pertukaran informasi yang dianggap paling efektif dan prosesnya dapat dilakukan dengan cara yang sederhana. Komunikasi antarpribadi dianggap efektif dan berhasil jika dalam interaksi tersebut pesan yang ingin disampaikan dapat diterima secara tepat oleh komunikan atau dengan kata lain, jika kebutuhan atau tujuan individu sudah tercapai.

Salah satu faktor yang paling penting dalam keberhasilan komunikasi antarpribadi adalah bagaimana kedua belah pihak yang terlibat dalam komunikasi memiliki pandangan atau memaknai pesan yang disampaikan oleh lawan komunikasinya. Hal inilah yang dilakukan Najwa untuk membuat para narasumbernya merasa nyaman dan tidak merasa terintimidasi dengan pertanyaan-pertanyaan yang diberikan oleh Najwa sehingga komunikasi di antara mereka dapat terjalin dengan baik dan lancar.

Penulis tertarik melakukan analisis terhadap tokoh Najwa Shihab karena 
sosoknya yang sangat menginspirasi banyak orang, cerdas, dan mampu bersifat kritis dalam menanggapi sesuatu. Kepiawaiannya dalam berbicara dan berkomunikasi dengan orang lain juga membuat penulis kagum. Apalagi ketika dia membawakan program talkshow "Mata Najwa" di Metro TV, beliau mampu melakukan komunikasi persuasif yang mendorong narasumbernya untuk menjawab setiap pertanyaan yang diberikannya, tanpa memperlihatkan unsur intimidasi di dalam setiap komunikasi yang disampaikannya.

Berdasarkan penjelasan yang sudah dipaparkan sebelumnya di dalam tulisan ini, maka masalah yang akan dibahas yaitu tentang bagaimana komunikasi antarpribadi yang dilakukan Najwa Shihab jika dikaitkan dengan teori komunikasi antarpribadi.

\section{PEMBAHASAN}

Menurut Devito, komunikasi antarpribadi adalah proses pengiriman dan penerimaan pesan-pesan antara dua orang atau di antara sekelompok kecil orang-orang, dengan beberapa efek dan umpan balik seketika (Liliweri, 2015:26). Komunikasi antarpribadi dinilai sangat efektif untuk merubah perilaku orang lain, bila terdapat persamaan mengenai makna yang dibincangkan. Selama proses komunikasi antarpribadi berlangsung sangat penting terjadinya interaksi berbagi informasi dan perasaan antara individu dengan individu atau individu dengan antar individu, supaya terjadi umpan balik dan tidak menimbulkan kesalahpahaman dalam berkomunikasi.

Sebagai seorang presenter talkshow, Najwa Shihab pastinya sering melakukan komunikasi antarpribadi dengan narasumbernya di dalam acara tersebut. Selama proses komunikasi terjadi di antara kedua belah pihak terdapat berbagai informasi dan umpan balik dari masingmasing pihak. Najwa Shihab memiliki karakter yang bersifat kritis dan cerdas. Ia terus mencecar berbagai pertanyaan kepada narasumbernya untuk mendapatkan faktafakta baru yang ditunggu oleh masyarakat. Ia menggunakan kemampuan komunikasi antarpribadinya dengan sangat baik, sehingga banyak masyarakat yang menyukai program acara yang dibawakannya.

Sudah banyak narasumber yang diwawancarai olehnya, mulai dari orang-orang atau public figure yang terkait isu-isu politik maupun yang memiliki pengaruh dalam Indonesia. Najwa Shihab mampu menempatkan dirinya ketika berkomunikasi dengan narasumbernya, sehingga dia mampu untuk menghindari kesalahpahaman dengan lawan bicaranya. Padahal jika dilihat dalam proses berkomunikasi yang dilakukannya, Nana bersifat begitu agresif dalam memberikan pertanyaan sehingga lawan bicaranya tidak bisa mengelak dengan pertanyaan yang diberikannya. Mungkin jika orang yang tidak mempunyai kompetensi dalam berkomunikasi antarpribadi, hal itu bisa menimbulkan konflik dan kesalahpahaman di antara kedua belah pihak.

Kompetensi komunikasi adalah kemampuan untuk berkomunikasi dalam cara yang diterima secara sosial. Untuk hubungan interpersonal, ini melibatkan interaksi pembicara dengan orang lain dalam hal presentasi vokal, kontrol pesan, perintah bahasa, penampilan fisik, dan sebagainya (Liliweri, 2015: 18). Dalam hal ini dapat dilihat jika Najwa Shihab memiliki kompetensi komunikasi yang sangat baik ketika melakukan praktik komunikasi antarpribadi. Cara Nana menghidupkan suasana ketika di atas panggung membawakan program acara "Mata Najwa" sangat baik. Mulai dari cara ia mendengarkan orang lain, memberikan respon terhadap pernyataan yang diberikan narasumbernya, serta proses tatap muka yang intens namun tidak memberikan kesan intimidasi, mampu diorganisirnya dengan cara yang bijak sehingga tidak menimbulkan misunderstanding di antara kedua belah pihak. 
Menurut De Vito (Liliweri, 1991: 13) ciri-ciri komunikasi antarpribadi antara lain: a) Keterbukaan (openness), yaitu sikap menanggapi informasi dengan hati yang gembira saat berinteraksi dalam hubungan antarpribadi; b) Empati (empathy), yaitu situasi dimana komunikan turut merasakan apa yang dirasa oleh orang lain; c) Dukungan (supportiveness), yaitu situasi terbuka untuk mendukung komunikasi yang efektif; d) Rasa positif (positiveness), yaitu perasaan positif dalam diri yang turut mendorong orang lain untuk aktif berpartisipasi dan menciptakan suasana komunikasi yang kondusif; e) Kesetaraan (equality), yaitu pengakuan tersembunyi dalam diri kedua belah pihak untuk saling menghargai.

Praktik komunikasi antarpribadi yang dilakukan oleh Najwa Shihab, di dalamnya terdapat beberapa ciri-ciri yang disebutkan di atas, baik itu dalam komunikasi yang terjalin dengan narasumbernya di panggung ataupun komunikasi dengan anggota keluarganya. Nana mempunyai sikap keterbukaan di dalam dirinya. Contohnya ketika ia berkomunikasi dengan ayahnya, Quraish Shihab tentang pendidikan dan kisah asmaranya.

Pada saat Nana duduk di kelas 2 SMU, ia berkesempatan mendapat AFS (America Field Service), program pertukaran pelajar ke Amerika Serikat. Awalnya keluarga Nana menolak untuk memberikan izin kepada Nana untuk pergi ke Amerika Serikat karena harus melepas anak perempuan yang baru berusia 16 tahun selama setahun untuk tinggal di negara orang bersama dengan keluarga asuh.

"Sempat terjadi perdebatan keluarga. Waktu itu yang paling mendukung ayah saya. Apa pun untuk pendidikan akan diperbolehkan, dalam usia itu pun beliau sudah memberikan kepercayaan, walaupun di sana dia sudah dibekali agama, mereka percaya shalatnya tidak akan ditinggal. Dan alhamdulillah saya bisa menjaga kepercayaan itu," cerita Nana.

$$
\text { Quraish Shihab (ayah Nana) }
$$
mengatakan, keterbukaan dalam keluarga harus sangat diperhatikan agar terjalin komunikasi dua arah. Karena sikap keterbukaan yang tercipta di antara Nana dan kedua orangtuanya, maka akhirnya dia diberikan izin oleh orangtuanya untuk mengikuti program pertukaran pelajar tersebut. Rasa saling percaya yang tercipta di antara kedua belah pihak membuat komunikasi yang terbangun juga menjadi efektif dan memberikan umpan balik yang positif.

Tidak hanya persoalan pendidikan, kebebasan juga diberikan oleh sang ayah untuk menentukan pasangan hidupnya.

"Bahkan saat saya memutuskan untuk nikah muda, 20 tahun, ayah memberi kepercayaan. Bagi beliau yang penting kuliah selesai." Menjelang pernikahan, kata Nana, keluarga sempat ragu, tapi karena pengalaman kakak yang nikah saat usia 19 tahun akhirnya diizinkan. Tapi sebelum itu mereka sekeluarga umroh dulu. "Di sana ayah bertanya, 'udah mantep?' saya jawab, 'udah'. Ya sudah diizinkan," tutur Nana.

Sikap empati juga ditunjukkan Najwa Shihab ketika ia melakukan liputan langsung di Aceh pada saat bencana tsunami melanda kawasan itu. Nana sangat berempati dengan keadaan yang terjadi disana. Ia menjadi saksi mata kedahsyatan musibah tsunami tersebut dan berada di tengah tumpukan mayat yang berserakan. Ketika melakukan liputan langsung, Nana tampak begitu emosional sehingga ia tak kuasa menahan air matanya di hadapan kamera. Ia turut merasakan kesedihan yang dirasakan oleh keluarga korban yang terkena musibah tsunami itu.

Diri merupakan semua ciri seperti jenis kelamin, pengalaman, sifat-sifat, latar belakang budaya, pendidikan, dan sebagainya yang melekat pada diri individu. Terdapat tiga aspek fundamental diri yang mempengaruhi komunikasi individu yakni konsep diri/selfconcept (cara melihat diri sendiri), kesadaran 
diri/self-awareness (wawasan dan pengetahuan tentang diri sendiri), dan harga diri / self-esteem (nilai diri sendiri).

Joseph A. Devito mendefinisikan konsep diri sebagai perasaan dan pemikiran mengenai kelebihan dan kekurangan, kemampuan dan keterbatasan, aspirasi dan cara pandang. Dari definisi tersebut, maka dapat dikatakan bahwa konsep diri merupakan gambaran seseorang tentang diri sendiri, baik yang bersifat fisik, sosial maupun psikologis, yang diperoleh melalui interaksinya dengan orang lain (Devito, 2007:58).

Konsep diri bukan merupakan faktor yang dibawa sejak lahir, melainkan faktor yang dipelajari dan terbentuk melalui pengalaman individu dalam berhubungan dengan orang lain. Dalam berinteraksi ini, setiap individu akan menerima tanggapan. Tanggapan yang diterima tersebut akan dijadikan cermin bagi individu untuk menilai dan memandang dirinya sendiri.

Najwa Shihab dikenal sebagai salah satu jurnalis senior tersukses di Indonesia yang saat ini semakin dipuja-puja banyak orang berkat kepiawaiannya memandu program talkshow bertemakan politik "Mata Najwa". Kenapa dia disebut sebagai 'contoh langka' jurnalis Indonesia? Karena tidak bisa dipungkiri, sejak pertama kali ngetop berkat liputan siaran langsungnya mengenai tragedi Tsunami Aceh tahun 2004 lalu sampai kini menjadi 'tuan rumah' di program-nya sendiri, perjalanan karir Najwa telah membawa banyak perubahan dan pengaruh luar biasa di dunia jurnalistik tanah air.

Konsep diri yang ideal dan positif yang ditunjukkan dalam diri Najwa Shihab membuat banyak orang semakin mengaguminya, tidak terkecuali anak-anak muda penerus bangsa. Selama 7 tahun memandu program talkshow "Mata Najwa", Najwa Shihab membawa banyak perubahan dan pengaruh terhadap pandangan anak muda terhadap panggung politik. Citra Najwa sebagai pemandu talkshow yang tegas, independen, berani, namun tetap bisa menyuguhkan pertanyaan dengan ramah tamah membuat setiap episode dari Mata Najwa mudah dinikmati oleh penonton berbagai kalangan, tidak terkecuali bagi anak muda yang meski sebelumnya tidak terlalu suka memantau perkembangan panggung politik.

Konsep pengemasan "Mata Najwa" sebagai talkshow politik juga terbilang beda dari talkshow politik lainnya. Bukan hanya sekedar tanya dan jawab, "Mata Najwa" sering hadir dengan konsep seperti mengorek sisi lain dari pejabat publik tersohor yang belum pernah diketahui oleh publik sebelumnya, atau konsep debat antar dua tokoh atau dua kubu dari panggung politik untuk saling beradu argumen.

Ini tidak terlepas dari campur tangan Najwa sebagai sang 'tuan rumah' yang selalu bisa memandu keseluruhan acara dengan lugas, yang sering membumbui keseruan acara dengan melontarkan pertanyaan-pertanyaan spontan yang tidak pernah diduga oleh bintang tamu maupun pemirsa. Bukti nyata betapa "Mata Najwa" dan Najwa Shihab sangat digemari anak muda masa kini adalah suksesnya gelaran "Mata Najwa On Stage" di berbagai kampus di kota-kota besar seperti, Jakarta, Surabaya, Malang, Medan, dan masih banyak lainnya.

Setiap gelaran "Mata Najwa On Stage" selalu dibanjiri ribuan mahasiswa dan mahasiswi yang antusias untuk melihat langsung karakter tokoh politik negeri serta berinteraksi langsung dengan cara mengajukan pertanyaan seputar kebijakan pemerintahan.

Kesadaran diri menunjukkan seberapa dalam kita mengenal diri kita sendiri. Mengenal bagaimana konsep diri merupakan salah satu cara untuk meningkatkan kesadaran diri. Kesadaran diri menjadi landasan bagi semua bentuk dan fungsi komunikasi. 
Mendengarkan adalah langkah pertama menuju ke arah komunikasi interpersonal sekaligus sebagai sebuah keahlian dalam studi komunikasi antarpribadi. Mendengarkan jelas merupakan langkah pertama menuju terciptanya pembicaraan, baik pada diri komunikator maupun komunikannya. Untuk menciptakan komunikasi antarpribadi yang efektif, pendengar harus memahami bagaimana cara 'mendengarkan' yang baik dan benar. Jika tidak, mungkin pesan yang sampai menjadi tidak jelas.

Najwa Shihab merupakan seorang pendengar yang baik, apalagi ketika melakukan komunikasi antarpribadi dengan anaknya, Izzat Assegaf. Ia tetap memberikan kebebasan kepada anaknya namun masih dalam kontrol/pengawasan darinya. Ia juga menjadi tempat untuk mencurahkan keluh kesah bagi anak semata wayangnya itu. Najwa sudah mengajarkan anaknya untuk mandiri sejak dini. Salah satunya yaitu memberikan literasi keuangan kepada anaknya. Hal ini disampaikannya dalam acara Wealth Wisdom, Ritz-Carlton Pasific Place, Kamis (3/8).

"Saya bukakan rekening tabungan untuk Izzat (nama anak Najwa). Saya kasih uang bulanan jadi dia mengatur uang sendiri kebutuhan dan keperluannya dengan uang yang ada. Kalau dia ingin membeli sesuatu sebelumnya dia tanya ke saya terlebih dahulu. Cukup enggak uang atau saya pinjamin dulu. Dan itu yang saya tanamkan kepada Izzat," ucap Najwa.

Najwa mendidik anaknya agar dapat mandiri dan menentukan pilihannya sendiri. Di tengah arus informasi yang begitu deras ini, dibutuhkan kemampuan mengelola informasi tersebut.

"Sekarang mudah sekali membeli sesuatu lewat online. Jadi kalau ada game baru dia bilang "mami boleh beli game baru nggak sekarang? Itu juga saya ajarkan kalau sekarang uangnya udah habis ya bulan depan belinya," ucapnya. Najwa menerapkan konsep tersebut kepada anaknya, karena dulu dirinya juga sudah diajarkan untuk mengatur keuangannya sendiri sejak kecil oleh kedua orangtunya.

\section{SIMPULAN}

Najwa Shihab memiliki kompetensi komunikasi yang sangat baik ketika melakukan praktik komunikasi antarpribadi. Cara Najwa menghidupkan suasana ketika di atas panggung membawakan program acara "Mata Najwa" sangat baik. Mulai dari cara ia mendengarkan orang lain, memberikan respon terhadap pernyataan yang diberikan narasumbernya, serta proses tatap muka yang intens namun tidak memberikan kesan intimidasi, mampu diorganisirnya dengan cara yang bijak sehingga tidak menimbulkan misunderstanding di antara kedua belah pihak. Praktik komunikasi antarpribadi yang dilakukan oleh Najwa Shihab, di dalamnya terdapat beberapa ciri-ciri komunikasi antarpribadi yang disebutkan dalam teori DeVito, yaitu keterbukaan, empati, dukungan, rasa positif, dan kesetaraan. Ciri-ciri tersebut ditunjukkan oleh Najwa, baik itu dalam komunikasi yang terjalin dengan narasumbernya di panggung ataupun komunikasi dengan anggota keluarganya. Di dalam lingkungan keluarganya, Najwa Shihab juga melakukan komunikasi antarpribadi. Ia juga merupakan seorang pendengar yang baik, apalagi ketika melakukan komunikasi antarpribadi dengan anaknya, Izzat Assegaf. Ia tetap memberikan kebebasan kepada anaknya namun masih dalam kontrol/pengawasan darinya. Ia juga menjadi tempat untuk mencurahkan keluh kesah bagi anak semata wayangnya itu. Najwa sudah mengajarkan anaknya untuk mandiri sejak dini. Salah satunya yaitu memberikan literasi keuangan kepada anaknya.

\section{DAFTAR PUSTAKA}

Beauty, V., (2017). Najwa Shihab adalah Contoh Langka Jurnalis Indonesia. Diunduh di https://life.idntimes.com/women/venitabeo 607/paraperempuanhebat-najwa-shihab- 
SIMBOLIKA, Vol. 3 (2) 2017: 71-77.

contoh-langka-jurnalis-indonesia-c1c2/ tanggal 12 November 2017

Biografi Tokoh: Referensi Biografi Tokoh dan Public Figure. Diunduh di http://bio.or.id/biografi-najwa-shihab/ tanggal 12 November 2017

Devito, J.. (2007). The Interpersonal Communication Book (Pearson International Edition). USA: Pearson Education, Inc.

Kartikawati, E., (2017). 7 Fakta Ini Buktikan Najwa Shihab Sosok Wanita Inspiratif. Diunduh di https://m.detik.com/wolipop/read/2017/o8/ 10/141549/3594030/1133/7-fakta-inibuktikan-najwa-shihab-sosok-wanitainspiratif/ tanggal 12 November 2017
Liliweri, A., (1997). Komunikasi Antarpribadi. Bandung: Citra Aditya Bakti.

(2015). Komunikasi AntarPersonal. Jakarta: Kencana Prenada Media.

Prasetiyo, W., (2017). Najwa Shihab Beri Edukasi Keuangan ke Anaknya Sejak Dini. Diunduh di

https://kumparan.com/@kumparannews/n ajwa-shihab-beri-edukasi-keuangan-keanaknya-sejak-dini/ tanggal 12 November 2017

Sunariyah. 2017. Najwa Shihab dan Gelar Habib di Keluarganya. Diunduh di http://news.liputan6.com/read/3051947/naj wa-shihab-dan-gelar-habib-di-keluarganya/ tanggal 12 November 2017

Wikipedia. Najwa Shihab. Diunduh di https://id.wikipedia.org/wiki/Najwa_Shiha b/ tanggal 12 November 2017 